\title{
Nasal Cavity and Paranasal Sinuses Cancer Pathologic Regional Lymph Nodes TNM
} Finding v8

National Cancer Institute

\section{Source}

National Cancer Institute. Nasal Cavity and Paranasal Sinuses Cancer Pathologic Regional Lymph Nodes TNM Finding v8. NCI Thesaurus. Code C133029.

A pathologic finding about one or more characteristics of nasal cavity and paranasal sinuses cancer, following the rules of the TNM AJCC v8 classification system as they pertain to staging of regional lymph nodes. 